\title{
Chemical Composition and Antibacterial Activity of Essential Oils of Tagetes minuta (Asteraceae) against Selected Plant Pathogenic Bacteria
}

\author{
Martin Muthee Gakuubi, ${ }^{1,2}$ John M. Wagacha, ${ }^{1}$ \\ Saifuddin F. Dossaji, ${ }^{1}$ and Wycliffe Wanzala ${ }^{3}$ \\ ${ }^{1}$ School of Biological Sciences, University of Nairobi, P.O. Box 30197-00100, Nairobi, Kenya \\ ${ }^{2}$ Department of Biology, Faculty of Science, Mwenge Catholic University, P.O. Box 1226, Moshi, Tanzania \\ ${ }^{3}$ Department of Biological Sciences, School of Science and Information Sciences, Maasai Mara University, \\ P.O. Box 861-20500, Narok, Kenya
}

Correspondence should be addressed to Martin Muthee Gakuubi; bromarto@yahoo.co.uk

Received 9 July 2016; Accepted 18 August 2016

Academic Editor: Joseph Falkinham

Copyright ( 2016 Martin Muthee Gakuubi et al. This is an open access article distributed under the Creative Commons Attribution License, which permits unrestricted use, distribution, and reproduction in any medium, provided the original work is properly cited.

\begin{abstract}
The objective of this study was to determine the chemical composition and antibacterial activity of essential oils (EOs) of Tagetes minuta against three phytopathogenic bacteria Pseudomonas savastanoi pv. phaseolicola, Xanthomonas axonopodis pv. phaseoli, and Xanthomonas axonopodis pv. manihotis. The essential oils were extracted using steam distillation method in a modified Clevengertype apparatus while antibacterial activity of the EOs was evaluated by disc diffusion method. Gas chromatography coupled to mass spectrometry (GC/MS) was used for analysis of the chemical profile of the EOs. Twenty compounds corresponding to $96 \%$ of the total essential oils were identified with $70 \%$ and $30 \%$ of the identified components being monoterpenes and sesquiterpenes, respectively. The essential oils of T. minuta revealed promising antibacterial activities against the test pathogens with Pseudomonas savastanoi pv. phaseolicola being the most susceptible with mean inhibition zone diameters of 41.83 and $44.83 \mathrm{~mm}$ after 24 and 48 hours, respectively. The minimum inhibitory concentrations and minimum bactericidal concentrations of the EOs on the test bacteria were in the ranges of $24-48 \mathrm{mg} / \mathrm{mL}$ and $95-190 \mathrm{mg} / \mathrm{mL}$, respectively. These findings provide a scientific basis for the use of T. minuta essential oils as a botanical pesticide for management of phytopathogenic bacteria.
\end{abstract}

\section{Introduction}

Advancement in agricultural technology coupled with improvement in pest and disease management has greatly enhanced global food productivity in the last few decades. However, despite this, agricultural losses occasioned by plant pathogens have remained an important constraint to the attainment of food security in many parts of the world. The combined preharvest and postharvest crop losses due to plant pathogens are estimated at $10-16 \%$ of global production $[1,2]$. While the threat of plant pathogenic bacteria to food security is less compared to that posed by phytopathogenic fungi, the economic impact of bacterial plant diseases cannot be underestimated [3].

Although the number of bacterial species has been estimated to vary greatly from tens of thousands to billions, only about 100 of these are known to be plant pathogens $[3,4]$. Nevertheless, phytopathogenic bacteria are responsible for huge losses in agriculture because most plants of agricultural importance are susceptible to at least one bacterial disease, and, for some crops, bacterial diseases are mostly the primary cause of yield losses [5]. Many plant pathogenic bacteria display enormous diversity in their life-history strategies and host range and host-pathogen interactions which make their impact on crop loss significant [6]. A single bacterial species can be responsible for hundreds of different plant diseases. For example, about 350 different plant diseases are caused by species within the genus Xanthomonas [7]. The most significant Gram-negative genera of bacterial plant pathogens are Agrobacterium, Erwinia, Pseudomonas, and Xanthomonas. All members of the four genera are single-celled, nonspore forming rods with the size of approximately $2.0 \times 0.7 \mu \mathrm{m}$. 
Gram-positive phytopathogenic bacteria on the other hand are mostly represented by members of four genera, namely, Arthrobacter, Clavibacter, Curtobacterium, and Rhodococcus, all of which are aerobic [8].

Control of plant bacterial diseases continues to be a major challenge due to several factors such as limited availability of bactericides [9] and development of microbial resistance to presently available chemical pesticides [10]. Furthermore, copper-based pesticides that are commonly used in management of many bacterial plant diseases have in recent years gained low public acceptance because of their toxicity which makes them a great health risk to humans, animals, and the environment $[9,11]$. Therefore, a search for, and development of, novel and environmentally friendly alternatives to synthetic bactericides for management of plant pathogenic bacteria is continuing and is of utmost importance. Currently, in addition to other natural sources, plants serve as a starting point in the search for new antimicrobial agents or serve as templates for new, more effective compounds with many plant-based antimicrobial agents having been successfully tested and commercialized [12, 13].

Among the major groups of plant products that have elicited strong interest among researchers in the quest for substitutes to synthetic antimicrobials are products of plants' secondary metabolism such as essential oils [14, 15]. Essential oils (EOs) also known as volatile oils or ethereal oils are aromatic oily liquids obtained from various aromatic plant parts. They are not produced by all plants but, rather, their occurrence is restricted to over 2000 plant varieties from about 60 families. Plant families that are particularly rich in essential oils include Asteraceae, Myrtaceae, Pinaceae, Zingiberaceae, Umbelliferae, Lamiaceae, Apiaceae, Rutaceae, and Poaceae [16]. Essential oils are a complex mixture of mainly terpenes particularly monoterpenes and sesquiterpenes and their oxygenated derivatives such as alcohols, aldehydes, esters, ethers, ketones, phenols, and oxides [10,15]. It is estimated that more than 1000 monoterpene and 3000 sesquiterpene structures are found in plant essential oils [17]. Essential oils are formed in the protoplasm of secretory cells and are isolated from whole plant or plant parts such as flowers, buds, seeds, leaves, twigs, bark, fruits, and roots by different methods such as steam distillation [16].

In recent years, a wide range of plant essential oils and their constituents have been investigated for their antibacterial properties against an array of plant pathogenic bacteria. For instance, Vasinauskiene et al. [13] found varying levels of antibacterial activity of seven essential oils against isolates of phytopathogenic bacteria: Erwinia carotovora subsp. carotovora, Xanthomonas vesicatoria, Pseudomonas marginalis $\mathrm{pv}$. marginalis, $P$. syringae pv. syringae, $P$. syringae pv. syringae, $P$. syringae pv. tomato, and Bacillus $\mathrm{sp}$. In another study, essential oils of Origanum acutidens (Hand.-Mazz.) Ietsw., Origanum rotundifolium Boiss., and Origanum vulgare L. were found to be highly effective against 25 plant pathogenic bacterial strains producing inhibition zone diameters between 8 and $48 \mathrm{~mm}$ [18]. The antibacterial activity of the three EOs was attributed to the presence of phenolic components such as carvacrol and thymol. Another study investigated the antimicrobial activities of essential oils from eighteen plants against Agrobacterium tumefaciens and Erwinia carotovora var. carotovora [10]. Remarkable antibacterial activity of the tested essential oils was reported with E. carotovora var. carotovora being more susceptible to the oils than A. tumefaciens. The objective of the current study was to determine the chemical composition of steam-distilled essential oils of T. minuta and the antibacterial activity of the oils against three phytopathogenic bacteria: Pseudomonas savastanoi pv. phaseolicola, Xanthomonas axonopodis pv. phaseoli, and Xanthomonas axonopodis pv. manihotis.

\section{Materials and Methods}

2.1. Collection of Plant Materials and Extraction of Essential Oils. Aerial parts (leaves, flowers, and stems) of T. minuta were collected at the flowering stage from Maseno area $\left(0^{\circ} 0^{\prime} 21.43^{\prime \prime} \mathrm{S}, 34^{\circ} 36^{\prime} 6.23^{\prime \prime} \mathrm{E}\right.$, and $\left.1524 \mathrm{MASL}\right)$ Kisumu County, Kenya. Essential oils were extracted using the steam distillation method in a modified Clevenger-type apparatus [19]. Plant materials were cut into small pieces $(\approx 10 \mathrm{~cm}$ long) and weighed and approximately $4 \mathrm{~kg}$ was loaded into the distillation tank that formed part of the steam distillation setup. The plant materials were subjected to steam distillation with the collection of oils starting after a heating time of about 40 minutes and continued until no more essential oil was obtained. After the distillation process was complete, the volatile essential oils were removed from the top of the hydrosol and dried over anhydrous sodium sulphate $\left(\mathrm{Na}_{2} \mathrm{SO}_{4}\right)$. The oils were filtered using Whatman filter paper (number 1), collected into airtight glass vials, and stored at $-20^{\circ} \mathrm{C}$ until the time when they were required for chemical analysis and antibacterial bioassays. A subsample of the collected plant materials was taken to the herbarium at the School of Biological Sciences, University of Nairobi, Kenya, for further identification and authentication by a plant taxonomist. A voucher specimen (MMG2015/01) was deposited at the University of Nairobi herbarium.

2.2. Plant Pathogenic Bacterial Strains. Three economically important bacterial plant pathogens used as test pathogens in the study were retrieved from the culture collection center at the Plant Pathology Laboratory, Department of Plant Science and Crop Protection, University of Nairobi. Pseudomonas savastanoi pv. phaseolicola and Xanthomonas axonopodis pv. phaseoli had been isolated from common bean (Phaseolus vulgaris L.) while Xanthomonas axonopodis pv. manihotis had been isolated from cassava (Manihot esculenta Crantz). Confirmation of the identity of the pathogens was done based on their cultural, morphological, and biochemical characteristics.

\subsection{Retrieval of Test Pathogens and Preparation of Bacterial} Inocula. Stock culture of each of the test bacteria maintained at $-20^{\circ} \mathrm{C}$ was retrieved by subculturing on nutrient agar (NA) plates. Three pure colonies of the same morphological type were selected from NA plates and aseptically transferred into test tubes containing $10 \mathrm{~mL}$ of Mueller-Hinton broth (MHB) using a sterile loop. The culture tubes were then incubated 
at $37^{\circ} \mathrm{C}$ for 24 hours to obtain fresh cultures. McFarland standard was used as a reference to adjust the turbidity of bacterial suspensions to be within the required range. Exactly $0.5 \mathrm{McF}$ arland equivalent turbidity standard was prepared by mixing $0.05 \mathrm{~mL}$ of $1 \%$ barium chloride dehydrate with $9.95 \mathrm{~mL}$ of $1 \%$ sulfuric acid. Bacterial suspensions were prepared in sterile saline solution which was prepared by dissolving $0.85 \mathrm{~g}$ of $\mathrm{NaCl}$ in $100 \mathrm{~mL}$ of distilled water and autoclaving for 15 minutes at $121^{\circ} \mathrm{C}$ and $15 \mathrm{psi}$ pressure. The turbidity of the bacterial suspensions for bioassays was adjusted to $0.5 \mathrm{McF}$ arland standards, equivalent to $1.5 \times$ $10^{8} \mathrm{CFU} / \mathrm{mL}$.

\subsection{Assessment of Antibacterial Activity of Tagetes minuta} Essential Oils. Antibacterial activity of T. minuta essential oils was carried out using disc diffusion method also known as Kirby-Bauer antimicrobial susceptibility test as described by Souza et al. [20]. Two hundred microliters of bacteria suspension prepared from an overnight culture was adjusted to an optical density equal to $0.5 \mathrm{McF}$ arland standard and uniformly spread on Petri plates $(9 \mathrm{~cm}$ in diameter) containing MHA using a sterile L-shaped glass rod. Sterile Whatman filter paper discs (number $1,6 \mathrm{~mm}$ in diameter) were each impregnated with $10 \mu \mathrm{L}$ of undiluted crude $T$. minuta essential oil in a sterile biological safety cabinet. The discs were then aseptically placed at the center of the inoculated culture plates using sterile forceps. Dimethyl sulphoxide (DMSO) was used as a negative control while Enrich BM $^{\circledR}$ (immunomodulator2-bromo-2-nitropropane1,3 diol), a broad-spectrum bactericide used in the control of bacterial diseases such as halo blight, bacterial wilt, and bacterial spot, was used as a positive control. The plates were refrigerated at $4^{\circ} \mathrm{C}$ for 2 hours to allow the essential oils to diffuse into the agar medium and finally incubated upside down at $37^{\circ} \mathrm{C}$ for 48 hours. The tests were conducted in triplicate and measurement of the inhibition zones was done after 24 and 48 hours.

The sensitivity of individual bacteria to the essential oil was ranked based on the inhibition zone values expressed in millimeters ( $\mathrm{mm}$ ) as follows: not sensitive (-) for total zone diameters of $\leq 8 \mathrm{~mm}$; sensitive $(+)$ for diameters between 8 and $14 \mathrm{~mm}$; very sensitive $(++)$ for zone diameters between 15 and $19 \mathrm{~mm}$; and extremely sensitive $(+++)$ for zone diameters of $\geq 20 \mathrm{~mm}$ [21, 22]. The bioassays were conducted in a biological safety cabinet and in accordance with the protocols of Clinical and Laboratory Standards Institute (CLSI) formerly National Committee for Clinical Laboratory Standards (NCCLS).

2.5. Antibacterial Activity at Different Concentrations of Tagetes minuta Essential Oils. The activity of T. minuta essential oils at seven concentration levels was assessed using the disc diffusion method following the procedure described by Clara et al. [23] with some modifications. Two hundred microliters of bacterial inocula (approximately $10^{8} \mathrm{CFU} / \mathrm{mL}$ ) was uniformly spread on Muller-Hinton Agar (MHA) Petri plates. Serial dilutions of T. minuta essential oil were prepared with DMSO. The essential oils were diluted to the following serial geometric dilutions: 50\%, 25\%, 12.5\%, 6.25\%, 3.13\%, $1.56 \%$, and $0.78 \%$. Sterile Whatman filter paper discs (number $1,6 \mathrm{~mm}$ in diameter) were impregnated with $10 \mu \mathrm{L}$ of different essential oil concentrations and aseptically placed at the center of the inoculated culture plates. The plates were placed in a refrigerator at $4^{\circ} \mathrm{C}$ for 2 hours to allow the essential oils to diffuse into the agar. The plates were then incubated at $28^{\circ} \mathrm{C}$ for 48 hours. The tests were conducted in triplicate and in addition to evaluating the activity of different concentrations of essential oil against the test bacteria; this bioassay was also used to estimate the minimum inhibition concentrations (MICs) of the EOs on the pathogens [23].

2.6. Assessment of the Minimum Inhibitory Concentrations and Minimum Bactericidal Concentration. Tube dilution method as described by Caburian and Osi [24] with some modifications was used to assess the minimum inhibitory concentrations (MICs) and minimum bactericidal concentrations (MBCs) of the essential oils against the test bacteria. Twelve sterile screw-capped falcon tubes $(15 \mathrm{~mL})$ were numbered $\# 1$ to \#11 and the last one was numbered as \#13. One milliliter of Muller-Hinton broth was introduced into tubes \#2 to \#11. One milliliter of T. minuta essential oil was pipetted into tubes $\# 1$ and \#2, and the two tubes were capped and vortexed for 5 seconds; one milliliter was withdrawn from the contents of tube \#2 and transferred to tube \#3; after capping the tube and mixing by vortexing the contents, one milliliter from the contents of tube \#3 was withdrawn and transferred to tube $\# 4$ and the process repeated until $1.0 \mathrm{~mL}$ from tube \#9 was added to tube \#10. Fifty microliters of standardized bacterial inocula (approximately $10^{8} \mathrm{CFU} / \mathrm{mL}$ ) was then introduced into tubes \#1 to \#11 and to tube \#13. To tube \#13,0.5 mL of the standard bactericide Enrich BM prepared according to the manufacturer's instructions was added. Tween $20(0.05 \%)$ was added to the essential oil prior to its application into the tubes to improve the oil solubility. The tubes were then incubated at $37^{\circ} \mathrm{C}$ for 48 hours.

After incubation, the tubes were examined for growth by observing for any turbidity. The tube with the lowest concentration (highest dilution) of the essential oil at which no visible growth or turbidity was observed was reported as the minimum inhibitory concentration of the oil on the test bacteria [25]. The tubes were shaken to homogenize the contents and $0.01 \mathrm{~mL}$ of the contents of each tube was subcultured by streaking Mueller-Hinton agar plates. The plates were incubated at $37^{\circ} \mathrm{C}$ for 24 hours and then observed for any growth of colonies. Minimum bactericidal concentration was determined as the highest dilution (lowest concentration) of essential oil at which no growth occurred following the subculturing onto MHA plates [25].

\subsection{Gas Chromatography-Mass Spectrometry Analyses of} Tagetes minuta Essential Oils. Gas chromatography (GC) coupled to mass spectrometry (MS) was used to establish the chemical composition of the EOs. Three replicates (each taken from a different extraction batch) of $1 \mathrm{mg}$ of $T$. minuta essential oils were separately weighed and diluted in $1 \mathrm{~mL}$ of dichloromethane to make a stock solution. From the stock 
solution, further dilution was made as follows: $100 \mu \mathrm{l}$ of the stock was topped up to $1 \mathrm{~mL}$ with dichloromethane and analyzed on an HP-7890A (Agilent Technologies, Wilmington, USA) GC connected to an HP 5975 C (Agilent Technologies, Wilmington, USA) MS. The gas chromatography equipment was fitted with HP-5MS capillary column; $30 \mathrm{~m} \times 0.25 \mathrm{~mm}$ internal diameter; and $0.25 \mu \mathrm{m}$ film thickness with $5 \%$ phenyl methyl silicone as the stationary phase (J\&W Scientific, Folsom, USA). The operating conditions were as follows: carrier gas was helium with a flow rate of $1.2 \mathrm{~mL} / \mathrm{min}$, constant flow mode; splitless injection mode; oven temperature $\left(35^{\circ} \mathrm{C}\right.$ for $5 \mathrm{~min}$ to $280^{\circ} \mathrm{C}$ at $10^{\circ} \mathrm{C} / \mathrm{min}$ for $10.5 \mathrm{~min}$ with a run time of $50 \mathrm{~min})$; and injection volume $(1 \mu \mathrm{L})$. The components of the essential oil were identified on the basis of their retention indices (RI) (determined with reference to a homologous series of normal alkanes $\mathrm{C}_{5}-\mathrm{C}_{31}$ ) and calculated based on a quasi-linear equation proposed by van Den Dool and Kratz [26] for temperature-programmed retention index. Identification of essential oil components was further verified by comparison of their MS fragmentation patterns with those reported in the mass spectra library database (NIST05a and Adams MS HP, USA). Quantitative determination of the constituents was made using the calibration curve of the dose-peak area of a pure compound (1,8-cineole, $99 \%$, Gillingham, Dorset, England), with the relative amount of each individual component expressed as percentage of the peak area relative to the total peak area.

2.8. Data Analyses. Data were analyzed using the PROC ANOVA procedure of GENSTAT version 15 and significant differences among means compared using Fisher's Protected LSD at 5\% probability level. The growth inhibitory effects of the essential oils against the test bacteria were expressed as mean \pm standard error of the mean inhibition zones diameter $(\mathrm{mm})$. Linear regression analysis was performed to determine correlations between different concentrations of essential oil and their overall antibacterial activity assessed as diameters of the inhibition zone. Standard dose-response curves were obtained by plotting essential oil concentrations $(\mathrm{mg} / \mathrm{mL})$ against the mean inhibition zone diameters $(\mathrm{mm})$.

\section{Results and Discussion}

3.1. Yield, Physical, and Chemical Characteristics of Tagetes minuta Essential Oils. A mean percent yield of $0.0594 \%$ w/w of essential oil was obtained from aerial parts of $T$. minuta. The EOs yield obtained was much higher than that obtained from previous studies from the same plant species from other parts of Kenya [27, 28] but lower than that obtained in two studies in Iran [29, 30]. Tagetes minuta essential oils obtained were less dense and insoluble in water. The EOs were however soluble in ethanol, dimethyl sulphoxide, and dichloromethane at a level of $1: 1(\mathrm{v} / \mathrm{v})$. The oils exhibited a pale yellowish-orange colour with a citruslike and turpentine-like odour. The oils were liquid at room temperature $\left(23 \pm 2^{\circ} \mathrm{C}\right)$ and maintained this state even in storage at $-20^{\circ} \mathrm{C}$. However, when mixed with DMSO in all the dilution levels used in the study, the essential oils froze when stored at $-20^{\circ} \mathrm{C}$. The essential oils had a density of $0.76 \mathrm{~g} / \mathrm{mL}$.

3.2. Antibacterial Activity of Tagetes minuta Essential Oils. In vitro studies demonstrated strong antibacterial activity of Tagetes minuta essential oils against the three test plant pathogenic bacteria, namely, Pseudomonas savastanoi pv. phaseolicola, Xanthomonas axonopodis pv. phaseoli, and Xanthomonas axonopodis pv. manihotis (Figure 1).

The activity of crude essential oils against the three bacteria isolates was within the extremely sensitive category (diameters of the inhibition zone larger than $20 \mathrm{~mm}$ ) after 24 and 48 hours of incubation (Table 1). The highest antibacterial activity of crude EOs was observed in P. savastanoi pv. phaseolicola with mean inhibition zone of $41.8 \mathrm{~mm}$ while, for $X$. axonopodis pv. phaseoli and $X$. axonopodis pv. manihotis, the oils produced inhibition zones of $26.8 \mathrm{~mm}$ after 24 hours of incubation. Antibacterial activity of T. minuta EOs has been reported in literature with most studies conducted on human pathogenic bacteria [31, 32]. Studies on the antimicrobial activity of essential oils from T. minuta and other plant species have generally revealed that Gram-positive bacteria are more susceptible to the effects of EOs in comparison to Gramnegative bacteria [31-33]. The three bacteria used in the current study were all Gram-negative; hence a comparison of this nature was not feasible.

The activities of the EOs on $X$. axonopodis pv. phaseoli and $P$. savastanoi pv. phaseolicola were significantly higher $(p \leq 0.05)$ after 48 hours in comparison to those recorded after 24 hours. However, there was no significant difference $(p \geq 0.05)$ in the antibacterial activity of Enrich BM on $X$. axonopodis pv. phaseoli and P. savastanoi pv. phaseolicola in the two incubation regimes. Enrich BM, the standard bactericide used as a positive control, showed the highest antibacterial activity against $X$. axonopodis pv. manihotis producing mean inhibition zones of 35.2 and $37.0 \mathrm{~mm}$ after 24 and 48 hours, respectively (Figure 2). Generally, P. savastano $i$ pv. phaseolicola and X. axonopodis pv. manihotis showed the highest and lowest susceptibility to the essential oils, respectively.

3.3. Antibacterial Activity of Different Concentrations of Tagetes minuta Essential Oils. There was a concentrationdependent inhibitory activity of EOs against the test bacteria. Thus, as the concentration of the essential oils increased, the activity of the oils against the test bacteria increased (Table 2). However, the inhibition zones produced at different concentrations of the essential oils varied from one bacterial species to another. Dose-dependent response of bacteria to essential oils of $T$. minuta has been reported in [31, 32]. Other biological activities of T. minuta such as tick repellency $[27,34]$, antioxidative and anti-inflammatory effects [30], aphidicidial activity [35], and allelopathic effects [36] have all been shown to occur in a concentration-dependent manner.

3.4. Dose-Response Effects of the Essential Oils on the Growth of Bacteria. The dose-response model showed a significant correlation $(p \leq 0.05)$ between the concentrations of $T$. 


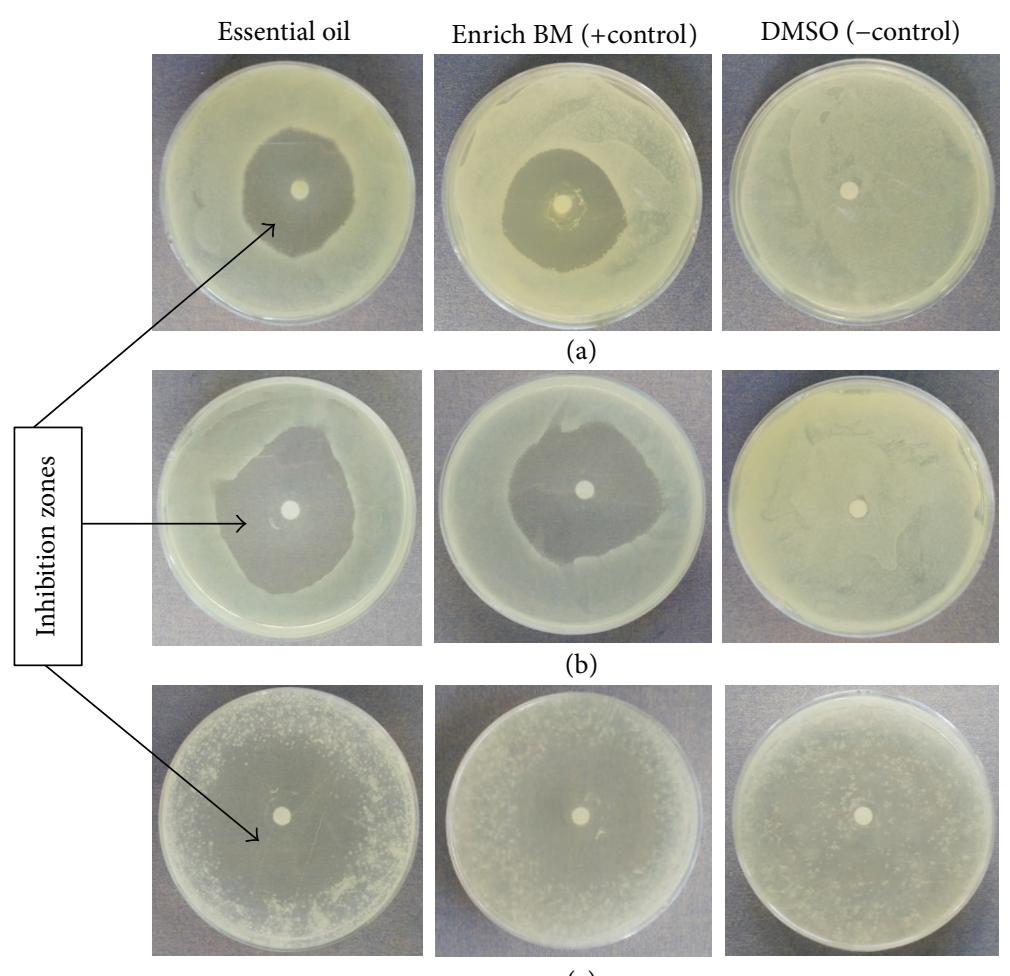

(c)

FIgURE 1: Inhibition zones of Tagetes minuta essential oils against X. axonopodis pv. manihotis (a), X. axonopodis pv. phaseoli (b), and $P$. savastanoi pv. phaseolicola (c) after 48 hours.

TABLE 1: Inhibition zones (mm) of Tagetes minuta essential oils and Enrich BM on three plant pathogenic bacteria after 24 and 48 hours.

\begin{tabular}{lcccccc}
\hline Bacteria species & Essential oil & $\begin{array}{c}24 \text { hours } \\
\text { Enrich BM } \\
(+ \text { ve control })\end{array}$ & $\begin{array}{c}\text { DMSO } \\
(- \text { ve control })\end{array}$ & Essential oil & $\begin{array}{c}48 \text { hours } \\
\text { Enrich BM } \\
(+ \text { control })\end{array}$ & $\begin{array}{c}\text { DMSO } \\
(- \text { ve control })\end{array}$ \\
\hline XAP & $26.83 \pm 0.60^{\mathrm{f}}$ & $29.50 \pm 0.29^{\mathrm{e}}$ & 0.00 & $27.67 \pm 0.88^{\text {ef }}$ & $29.50 \pm 0.29^{\mathrm{e}}$ & 0.00 \\
XAM & $26.83 \pm 0.17^{\mathrm{f}}$ & $35.17 \pm 0.73^{\mathrm{cd}}$ & 0.00 & $23.00 \pm 1.00^{\mathrm{g}}$ & $37.00 \pm 0.58^{\mathrm{c}}$ & 0.00 \\
PSP & $41.83 \pm 0.93^{\mathrm{b}}$ & $33.17 \pm 0.93^{\mathrm{d}}$ & 0.00 & $44.83 \pm 0.83^{\mathrm{a}}$ & $33.17 \pm 0.73^{\mathrm{d}}$ & 0.00 \\
\hline Mean & 31.83 & 32.61 & & 31.83 & 33.22 & \\
\hline
\end{tabular}

Values are mean \pm standard error of the mean for bioassays conducted in triplicate. Means followed by the same letter(s) for the two incubation regimes are not significantly different (multivariate analysis, Fisher's Protected LSD at $p \leq 0.05$ ).

XAP: Xanthomonas axonopodis pv. Phaseolicola; XAM: Xanthomonas axonopodis pv. Manihotis; and PSP: Pseudomonas savastanoi pv. Phaseolicola.

TABLE 2: Inhibition zones $(\mathrm{mm})$ of three bacterialspecies at different concentrations of Tagetes minuta essential oils after 48 hours of incubation.

\begin{tabular}{|c|c|c|c|c|c|c|c|c|c|}
\hline \multirow{2}{*}{ Bacteria } & \multicolumn{7}{|c|}{ Essential oil concentration $(\mathrm{mg} / \mathrm{mL}) * 10^{2}$} & \multirow{2}{*}{$\begin{array}{c}\text { DMSO } \\
\text { (-ve control) }\end{array}$} & \multirow{2}{*}{$\begin{array}{c}\mathrm{MIC} \\
(\mathrm{mg} / \mathrm{mL})\end{array}$} \\
\hline & 3.8 & 1.9 & 0.95 & 0.48 & 0.24 & 0.12 & 0.06 & & \\
\hline XAP & $17.33 \pm 0.60$ & $13.67 \pm 1.01$ & $11.17 \pm 0.60$ & $8.17 \pm 0.17$ & $\leq 8.00$ & $\leq 8.00$ & $\leq 8.00$ & 0.00 & 24.00 \\
\hline XAM & $12.83 \pm 0.60$ & $10.83 \pm 0.93$ & $10.50 \pm 0.29$ & $\leq 8.00$ & $\leq 8.00$ & $\leq 8.00$ & $\leq 8.00$ & 0.00 & 48.00 \\
\hline PSP & $21.33 \pm 0.44$ & $17.67 \pm 0.17$ & $13.17 \pm 0.60$ & $9.83 \pm 0.16$ & $8.17 \pm 0.17$ & $\leq 8.00$ & $\leq 8.00$ & 0.00 & 12.00 \\
\hline
\end{tabular}

Values are means \pm standard error of the mean for bioassay conducted in triplicate.

XAP: Xanthomonas axonopodis pv. phaseolicola; XAM: Xanthomonas axonopodis pv. manihotis; PSP: Pseudomonas savastanoi pv. phaseolicola; and MIC: minimum inhibitory concentration. 


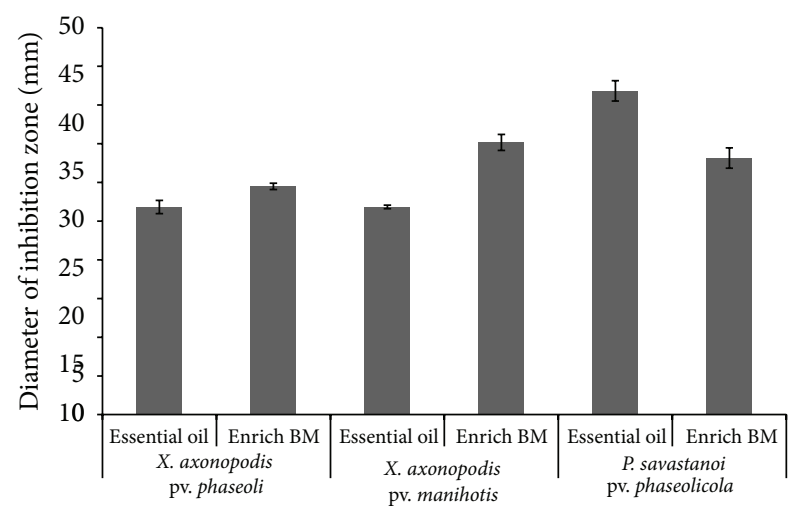

(a)

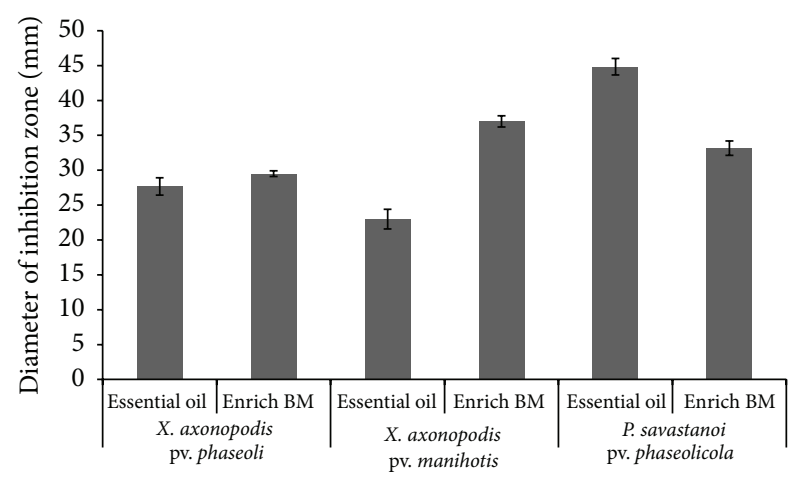

(b)

FIgURE 2: Growth inhibition of the test bacteria by T. minuta essential oils and Enrich BM after 24 hours (a) and 48 hours (b). Error bars represent standard error of mean.

minuta essential oils and the mean inhibition zones for the three test bacteria (Figure 3). The correlation coefficient values were as follows: $R^{2}, 0.94, p \leq 0.001 ; R^{2}, 0.91, p \leq 0.001$; and $R^{2}, 0.84, p=0.004$ for $X$. axonopodis pv. phaseoli, $P$. savastanoi pv. phaseolicola, and $X$. axonopodis pv. manihotis, respectively. The results thus indicated that 94,91 , and $84 \%$ of the variation in diameters of the inhibition zones in $X$. axonopodis pv. phaseoli, $P$. savastanoi pv. phaseolicola, and $X$. axonopodis pv. manihotis, respectively, were explained by variation in the concentration of the essential oils. It has previously been reported that antibacterial activity and indeed most biological activities of essential oils are dependent on their concentrations [31, 32]. The concentration-dependent antibacterial activity of EOs observed was attributed to changes in concentration of the active principles present in the EOs. This view is supported by several studies that have reported dose-dependent biological activities of various pure compounds isolated from essential oils [37, 38]. Thus, the concentration of the EOs increases, so does the active component present in the oils and hence there is an increase in the activity of the oils in this case represented by larger inhibition zones.

3.5. Minimum Inhibitory Concentrations and Minimum Bactericidal Concentrations. Minimum inhibitory concentrations

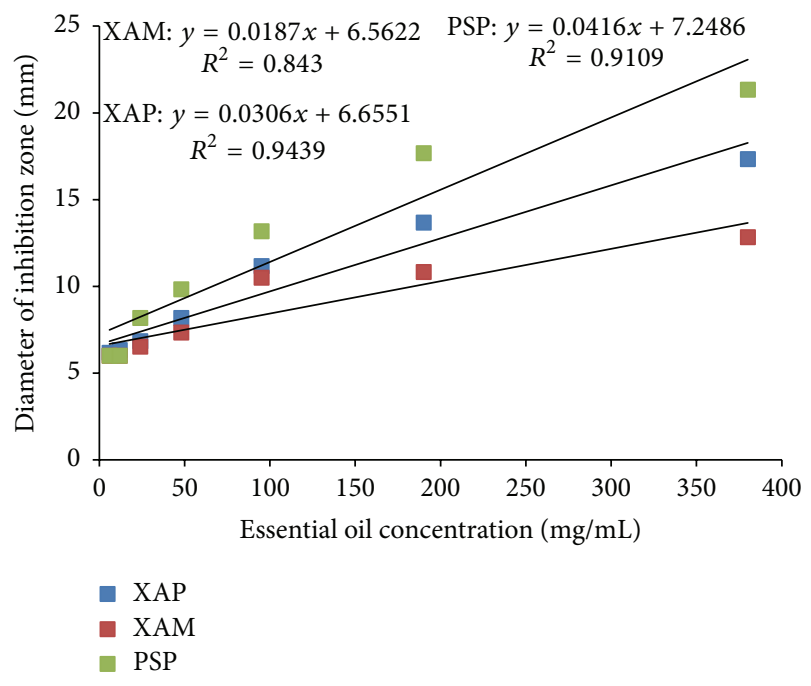

FIGURE 3: A dose-response curve of inhibition zone diameters ( $\mathrm{mm}$ ) against concentration of $T$. minuta essential oils $(\mathrm{mg} / \mathrm{mL})$ for the test bacteria. XAP: Xanthomonas axonopodis pv. phaseolicola; XAM: Xanthomonas axonopodis pv. manihotis; and PSP: Pseudomonas savastanoi $\mathrm{pv}$. phaseolicola.

(MICs) and minimum bactericidal concentrations (MBCs) of T. minuta essential oils on the three test bacteria are shown in Table 3. Minimum inhibitory concentrations values for the test bacteria ranged from 24 to $48 \mathrm{mg} / \mathrm{mL}$ with $X$. axonopodis pv. phaseoli and $P$. savastanoi pv. phaseolicola having the lowest value $(24 \mathrm{mg} / \mathrm{mL})$ and $X$. axonopodis $\mathrm{pv}$. manihotis having the highest value $(48 \mathrm{mg} / \mathrm{mL})$. The estimated MICs values obtained using disc diffusion methods were 12,24 , and $48 \mathrm{mg} / \mathrm{mL}$ for $P$. savastanoi pv. phaseolicola, Xanthomonas axonopodis pv. phaseoli, and $X$. axonopodis pv. manihotis, respectively. Minimum bactericidal concentrations of T. minuta essential oils on the three test bacteria were in the range of 95 to $190 \mathrm{mg} / \mathrm{mL}$. Xanthomonas axonopodis $\mathrm{pv}$. phaseoli and $P$. savastanoi pv. phaseolicola had the lowest MBCs $(95 \mathrm{mg} / \mathrm{mL})$ while $X$. axonopodis pv. manihotis had the highest $(190 \mathrm{mg} / \mathrm{mL})$. The variation in the MIC values obtained using disc diffusion and tube dilution methods is indicative of the difficulty that exists when comparing antimicrobial susceptibility results, which have been obtained using different methodologies, especially in regard to the minimal inhibitory concentrations [39, 40]. In this study, differences in the solubility, diffusion, and evaporation rates of the essential oils in agar and broth media could be some of the factors that contributed to the observed differences between the two methods.

3.6. Chemical Composition of the Essential Oils of Tagetes minuta. Twenty compounds corresponding to $96 \%$ of the total oil of T. minuta were identified (Figures 4 and 5). The essential oils comprised hydrocarbons mainly terpenes, a mixture of monoterpenes (70\%) and sesquiterpenes (30\%). The most abundant compounds identified in the essential oils were (E)-tagetone, dihydrotagetone, and alloocimene 


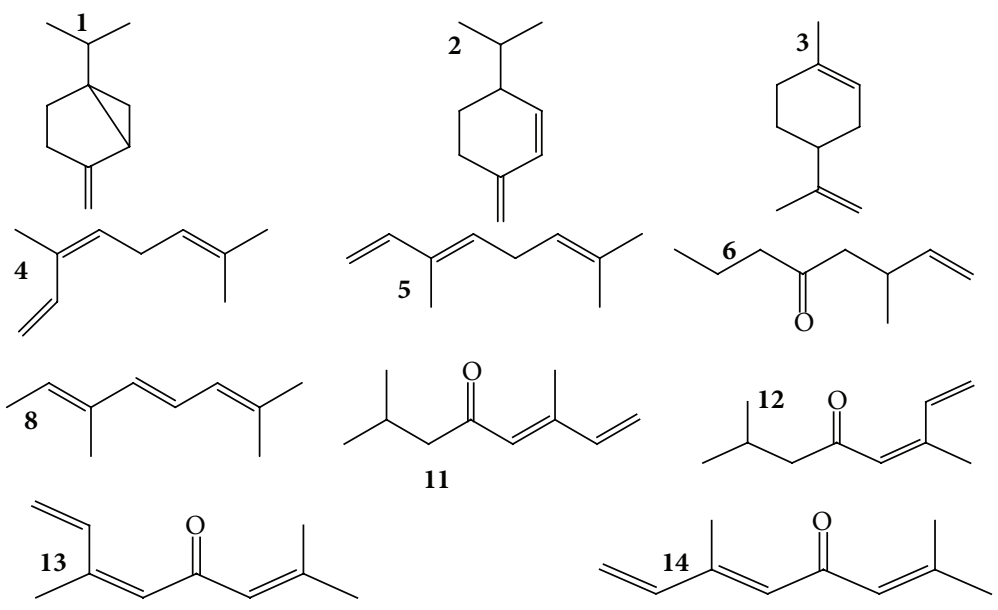

FIgURE 4: Chemical structures of monoterpenes identified in Tagetes minuta essential oils. (1) Sabinene, (2) $\alpha$-phellandrene, (3) limonene, (4) (Z)- $\beta$-ocimene, (5) (E)- $\beta$-ocimene, (6) dihydrotagetone, (8) alloocimene, (11) (Z)-tagetone, (12) (E)-tagetone, (13) (Z)-ocimenone, and (14) (E)-ocimenone.

TABLE 3: Minimum inhibitory concentrations and minimum bactericidal concentrations of essential oils of Tagetes minuta on three plant pathogenic bacteria.

\begin{tabular}{|c|c|c|c|c|c|c|c|}
\hline \multirow{2}{*}{ Tube/plate number } & \multirow{2}{*}{$\begin{array}{l}\text { EOs concentration } \\
\qquad(\mathrm{mg} / \mathrm{mL}) * 10^{2}\end{array}$} & \multicolumn{3}{|c|}{ Growth of bacteria in MHB tubes } & \multicolumn{3}{|c|}{ Growth of bacteria in MHA plates } \\
\hline & & XAP & XAM & PSP & XAP & XAM & PSP \\
\hline$\# 1$ & Crude EOs & - & - & - & - & - & - \\
\hline$\# 2$ & 3.8 & - & - & - & - & - & - \\
\hline$\# 3$ & 1.9 & - & - & - & - & - & - \\
\hline \#4 & 0.95 & - & - & - & - & + & - \\
\hline$\# 5$ & 0.48 & - & - & - & + & + & + \\
\hline \#6 & 0.24 & - & + & - & + & + & + \\
\hline$\# 7$ & 0.12 & + & + & + & + & + & + \\
\hline$\# 8$ & 0.06 & + & + & + & + & + & + \\
\hline \#9 & 0.03 & + & + & + & + & + & + \\
\hline$\# 10$ & 0.015 & + & + & + & + & + & + \\
\hline$\# 11$ & -ve control & + & + & + & + & + & + \\
\hline$\# 13$ & +ve control & - & - & - & - & - & - \\
\hline
\end{tabular}

[+]: growth; [-]: no growth of the bacteria; and XAP: X. axonopodis pv. phaseoli, XAM: X. axonopodis pv. manihotis, and PSP: P. savastanoi pv. Phaseolicola. MHB: Muller-Hinton broth; MHA: Muller-Hinton Agar; tube 1: bacterial inoculum and undiluted crude essential oils; tubes 2 to 10: MHB, bacterial inocula, and essential oils of different concentrations; tube 11: bacterial inoculum and MHB (-ve control); and tube 13: bacterial inoculum, MHB, and the standard bactericide (+ve control).

while the least abundant compound was silphiperfol-6ene. In summary, monoterpene hydrocarbons (30\%), oxygenated monoterpenes (25\%), and 3 unknown monoterpenes (15\%) occurred in relatively high concentrations compared to sesquiterpene hydrocarbons (25\%) and nonoxygenated sesquiterpenes and one unknown sesquiterpene (1\%).

Predominance of monoterpenes and sesquiterpenes in EOs of T. minuta in the current study was in agreement with earlier studies. A study on T. minuta EOs from three regions in Kenya, namely, Kasarani (Nairobi County), Bungoma (Bungoma County), and Bondo (Siaya County), found monoterpenes and sesquiterpenes hydrocarbons in the ratios of $3: 7,2: 8$, and $4: 6$, respectively [27]. These findings were also comparable with a number of earlier qualitative studies on the chemical composition of EOs of T. minuta that have identified dihydrotagetone, tagetones, ocimenes, limonene, and ocimenones as the most abundant constituents of $T$. minuta essential oils. In one such study [41], four monoterpene constituents-limonene, $\beta$-ocimene, dihydrotagetone, and tagetone-were found to represent more than $70 \%$ of $T$. minuta essential oil. Dihydrotagetone has been cited as one of the most abundant constituents of T. minuta oils from plants sampled from a wide range of countries such as Kenya $[28,42]$, Iran [32], Zambia [43], and the UK [44] constituting $16.7,33.9,30.0$, and $34.3 \%$ of the total oil, respectively.

\section{Conclusion}

Development of natural antimicrobial agents is a major step towards reduction of the negative effects associated with 


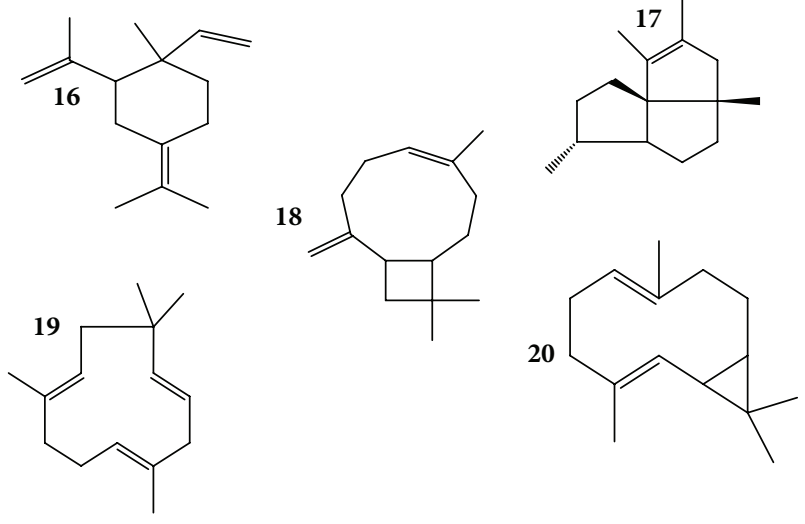

FIgURE 5: Chemical structures of sesquiterpenes identified in Tagetes minuta essential oils. (16) Elixene, (17) silphiperfol-6-ene, (18) (E)-caryophyllene, (19) $\alpha$-humulene, and (20) bicyclogermacrene.

synthetic chemical pesticides such as slow biodegradation, toxic residues in agricultural products, resistance development in targeted microorganisms, and general harmful effects on environment, humans, and animal. The objective of this study was to investigate the antibacterial activity of essential oils isolated from T. minuta against three plant pathogenic bacteria. In vitro studies revealed that the essential oils had a remarkable antibacterial activity against all the test bacteria, namely, Pseudomonas savastanoi pv. phaseolicola, Xanthomonas axonopodis pv. phaseoli, and Xanthomonas axonopodis pv. manihotis. This study therefore confirms the biopesticidal nature of T. minuta essential oils and their potential uses as cheap, safe, and effective alternative to chemical bactericides. To achieve this goal, however, the potential use of the EOs in management of bacteria plant diseases should be validated under field conditions.

\section{Competing Interests}

The authors declare that there are no competing interests regarding the publication of this paper.

\section{Acknowledgments}

The first author wishes to acknowledge the support received from Mwenge Catholic University, Moshi, Tanzania, in the form of an M.S. scholarship, the World Federation of Scientists (WFS) for a one-year research internship at the International Centre of Insect Physiology and Ecology (ICIPE) Nairobi, Kenya, and the National Commission for Science Technology and Innovation (NACOSTI) for the funding through Grant no. NACOSTI/RCD/ST\&I/7TH CALL/MSc/025.

\section{References}

[1] S. Chakraborty and A. C. Newton, "Climate change, plant diseases and food security: an overview," Plant Pathology, vol. 60, no. 1, pp. 2-14, 2011.
[2] J. Fletcher, C. Bender, B. Budowle et al., "Plant pathogen forensics: capabilities, needs, and recommendations," Microbiology and Molecular Biology Reviews, vol. 70, no. 2, pp. 450-471, 2006.

[3] G. N. Agrios, Plant Pathology, Elsevier Academic Press, San Diego, Calif, USA, 5th edition, 2005.

[4] P. D. Schloss and J. Handelsman, "Status of the microbial census," Microbiology and Molecular Biology Reviews, vol. 68, no. 4, pp. 686-691, 2004.

[5] S. R. Mishra, Bacterial Plant Diseases, Discovery Publishing House, New Delhi, India, 2003.

[6] J. J. Burdon and J. Silk, "Sources and patterns of diversity in plant-pathogenic fungi," Phytopathology, vol. 87, no. 7, pp. 664$669,1997$.

[7] F. Leyns, M. De Cleene, J.-G. Swings, and J. Deley, “The host range of the genus Xanthomonas," The Botanical Review, vol. 50, no. 3, pp. 308-356, 1984.

[8] J. F. Brown and H. J. Ogle, Plant Pathogens and Plant Diseases, Rockvale, Armidale, Australia, 1997.

[9] B. Kokoskova, D. Pouvova, and R. Pavela, "Effectiveness of plant essential oils against Erwinia amylovora, Pseudomonas syringae pv. syringae and associated saprophytic bacteria on/in host plants," Journal of Plant Pathology, vol. 93, no. 1, pp. 133-139, 2011.

[10] M. E. I. Badawy and S. A. M. Abdelgaleil, "Composition and antimicrobial activity of essential oils isolated from Egyptian plants against plant pathogenic bacteria and fungi," Industrial Crops and Products, vol. 52, pp. 776-782, 2014.

[11] G. Al-Samarrai, H. Singh, and M. Syarhabil, "Evaluating ecofriendly botanicals (natural plant extracts) as alternatives to synthetic fungicides," Annals of Agricultural and Environmental Medicine, vol. 19, no. 4, pp. 673-676, 2012.

[12] N. Raja, "Botanicals: sources for eco-friendly biopesticides," Journal of Biofertilizers \& Biopesticides, vol. 5, no. 1, article e122, 2014.

[13] M. Vasinauskiene, J. Radusiene, I. Zitikaite, and E. Surviliene, "Antibacterial activities of essential oils from aromatic and medicinal plants against growth of phytopathogenic bacteria," Agronomy Research, vol. 4, pp. 437-440, 2006.

[14] A. Gormez, S. Bozari, D. Yanmis, M. Gulluce, F. Sahin, and G. Agar, "Chemical composition and antibacterial activity of essential oils of two species of Lamiaceae against phytopathogenic bacteria," Polish Journal of Microbiology, vol. 64, no. 2, pp. 121-127, 2015.

[15] I. H. N. Bassolé and H. R. Juliani, "Essential oils in combination and their antimicrobial properties," Molecules, vol. 17, no. 4, pp. 3989-4006, 2012.

[16] S. D. Kocić-Tanackov and G. R. Dimić, "Antifungal activity of essential oils in the control of food-borne fungi growth and mycotoxin biosynthesis in food," in Microbial Pathogens and Strategies for Combating Them: Science, Technology and Education, A. Méndez-Vilas, Ed., pp. 838-849, Formatex Research Center, Badajoz, Spain, 2013.

[17] Y. A. H. Osman, E. M. Yaseen, and M. M. Farag, "Antimicrobial effect of some essential oils mixtures," Journal of Applied Sciences Research, vol. 5, no. 9, pp. 1265-1276, 2009.

[18] F. Dadasoglu, T. Aydin, R. Kotan et al., "Antibacterial activities of extracts and essential oils of three Origanum species against plant pathogenic bacteria and their potential use as seed disinfectants," Journal of Plant Pathology, vol. 93, no. 2, pp. 271$282,2011$. 
[19] J. F. Clevenger, "Apparatus for the determination of volatile oil," The Journal of the American Pharmaceutical Association, vol. 17, no. 4, pp. 345-349, 1928.

[20] E. L. Souza, E. O. Lima, K. R. Freire, and C. P. Sousa, "Inhibitory action of some essential oils and phytochemicals on the growth of various moulds isolated from foods," Brazilian Archives of Biology and Technology, vol. 48, no. 2, pp. 245-250, 2005.

[21] N. Celikel and G. Kavas, "Antimicrobial properties of some essential oils against some pathogenic microorganisms," Czech Journal of Food Sciences, vol. 26, no. 3, pp. 174-181, 2008.

[22] A. J. Babu, A. R. Sundari, J. Indumathi, R. V. N. Srujan, and M. Sravanthi, "Study on the antimicrobial activity and minimum inhibitory concentration of essential oils of spices," Veterinary World, vol. 4, no. 7, pp. 311-316, 2011.

[23] C. Clara, J. C. Matasyoh, I. N. Wagara, and J. Nakuvuma, "Antifungal activity of Monathotaxis littoralis essential oil against mycotoxigenic fungi isolated from maize," American Journal of Applied Chemistry, vol. 1, no. 4, pp. 54-60, 2013.

[24] A. B. Caburian and M. O. Osi, "Characterization and evaluation of antimicrobial activity of the essential oil from the leaves of Piper betle L," E-International Scientific Research Journal, vol. 2, no. 1, pp. 2-13, 2010.

[25] E. A. Quinto and M. G. Santos, "Microbiology," in A Guidebook to Plant Screening: Phytochemical and Biological, B. Q. Guevara, Ed., pp. 67-87, UST Publishing House, Manila, Philippines, 2005.

[26] H. van Den Dool and P. D. Kratz, "A generalization of the retention index system including linear temperature programmed gas-liquid partition chromatography," Journal of Chromatography A, vol. 11, pp. 463-471, 1963.

[27] O. B. Makanga, Composition and repellency of essential oils of Tagetes minuta from different zones in Kenya against brown ear tick (Rhipicephalus appendiculatus) [M.S. thesis], Kenyatta University, Nairobi, Kenya, 2012.

[28] W. Wanzala and S. B. Ogoma, "Chemical composition and mosquito repellency of essential oil of Tagetes minuta from the Southern slopes of Mount Elgon in Western Kenya," Journal of Essential Oil Bearing Plants, vol. 16, no. 2, pp. 216-232, 2013.

[29] M. H. Meshkatalsadat, J. Safaei-Ghomi, S. Moharramipour, and M. Nasseri, "Chemical characterization of volatile components of Tagetes minuta L. cultivated in south west of Iran by nano scale injection," Digest Journal of Nanomaterials and Biostructures, vol. 5, no. 1, pp. 101-106, 2010.

[30] P. Karimian, G. Kavoosi, and Z. Amirghofran, "Anti-oxidative and anti-inflammatory effects of Tagetes minuta essential oil in activated macrophages," Asian Pacific Journal of Tropical Biomedicine, vol. 4, no. 3, pp. 219-227, 2014.

[31] N. Y. Osée Muyima, S. Nziweni, and L. V. Mabinya, "Antimicrobial and antioxidative activities of Tagetes minuta, Lippia javanica and Foeniculum vulgare essential oils from the Eastern Cape Province of South Africa," Journal of Essential Oil Bearing Plants, vol. 7, no. 1, pp. 68-78, 2004.

[32] M. T. Shirazi, H. Gholami, G. Kavoosi, V. Rowshan, and A. Tafsiry, "Chemical composition, antioxidant, antimicrobial and cytotoxic activities of Tagetes minuta and Ocimum basilicum essential oils," Food Science \& Nutrition, vol. 2, no. 2, pp. 146$155,2014$.

[33] D. Trombetta, F. Castelli, M. G. Sarpietro et al., "Mechanisms of antibacterial action of three monoterpenes," Antimicrobial Agents and Chemotherapy, vol. 49, no. 6, pp. 2474-2478, 2005.

[34] I. T. F. Macedo, L. M. B. D. Oliveira, A. L. F. CamurçaVasconcelos et al., "In vitro effects of Coriandrum sativum,
Tagetes minuta, Alpinia zerumbet and Lantana camara essential oils on Haemonchus contortus," Revista Brasileira de Parasitologia Veterinária, vol. 22, no. 4, pp. 463-469, 2013.

[35] M. Işık and G. Görür, "Aphidicidial activity of seven essential oils against the cabbage aphid, Brevicoryne brassicae L. (Hemiptera: Aphididae)," Munis Entomology and Zoology, vol. 4, no. 2, pp. 424-431, 2009.

[36] N. Tabanca, G. Ma, D. S. Pasco et al., "Effect of essential oils and isolated compounds from Pimpinella species on NF- $\kappa \mathrm{B}$ : a target for antiinflammatory therapy," Phytotherapy Research, vol. 21, no. 8, pp. 741-745, 2007.

[37] J. Tangjitjaroenkun, W. Chavasiri, S. Thunyaharn, and C. Yompakdee, "Bactericidal effects and time-kill studies of the essential oil from the fruits of Zanthoxylum limonella on multidrug resistant bacteria," Journal of Essential Oil Research, vol. 24, no. 4, pp. 363-370, 2012.

[38] P. Hili, C. S. Evans, and R. G. Veness, "Antimicrobial action of essential oils: the effect of dimethylsulphoxide on the activity of cinnamon oil," Letters in Applied Microbiology, vol. 24, no. 4, pp. 269-275, 1997.

[39] K. I. Suhr and P. V. Nielsen, "Antifungal activity of essential oils evaluated by two different application techniques against rye bread spoilage fungi," Journal of Applied Microbiology, vol. 94, no. 4, pp. 665-674, 2003.

[40] K. Arora, D. R. Batish, P. H. Singh, and R. K. Kohli, "Allelopathic potential of the essential oil of wild marigold (Tagetes minuta L.) against some invasive weeds," Journal of Environmental and Agricultural Sciences, vol. 3, pp. 56-60, 2015.

[41] M. V. Garcia, J. Matias, J. C. Barros, D. P. de Lima, R. D. S. Lopes, and R. Andreotti, "Chemical identification of Tagetes minuta Linnaeus (Asteraceae) essential oil and its acaricidal effect on ticks," Revista Brasileira de Parasitologia Veterinaria, vol. 21, no. 4, pp. 405-411, 2012.

[42] W. Wanzala, Ethnobotanicals for management of the brown ear tick Rhipicephalus appendiculatus in western Kenya [Ph.D. thesis], Wageningen University, Wageningen, Netherlands, 2009.

[43] E. H. Chisowa, D. R. Hall, and D. I. Farman, "Chemical composition of the essential oil of Tagetes minuta L. from Zambia," Journal of Essential Oil Research, vol. 10, no. 2, pp. 183184, 1998.

[44] F. Senatore, F. Napolitano, M. A.-H. Mohamed, P. J. C. Harris, P. N. S. Mnkeni, and J. Henderson, "Antibacterial activity of Tagetes minuta L. (Asteraceae) essential oil with different chemical composition," Flavour and Fragrance Journal, vol. 19, no. 6, pp. 574-578, 2004. 

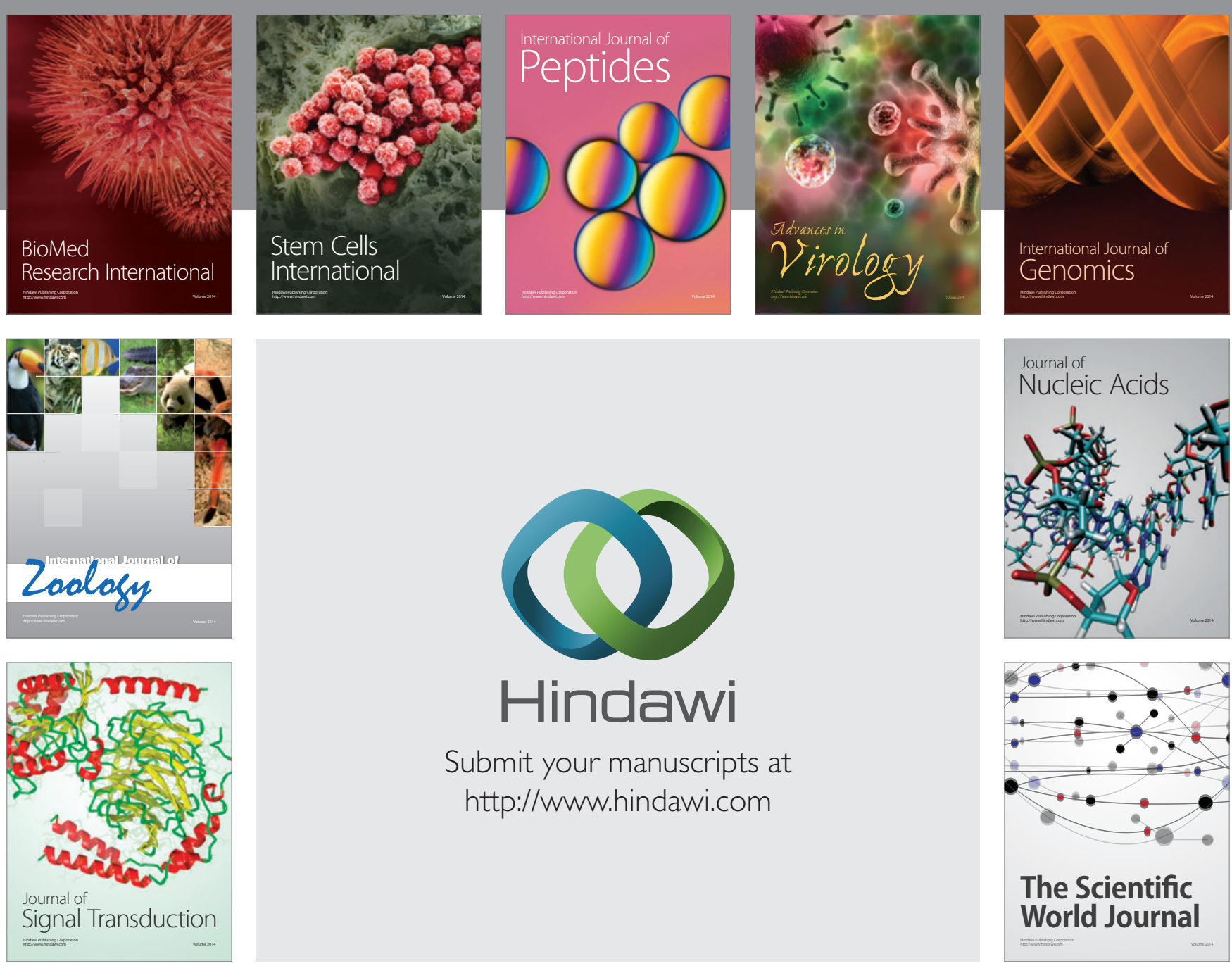

Submit your manuscripts at

http://www.hindawi.com
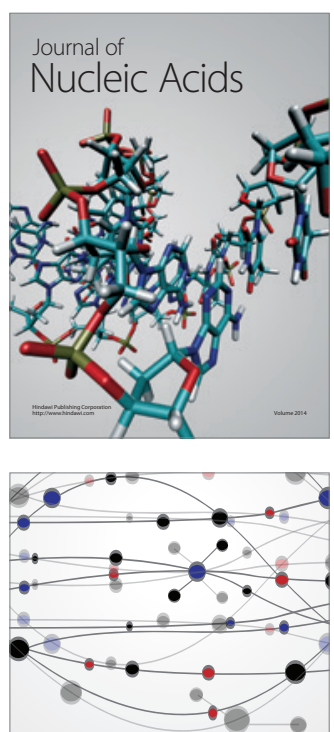

The Scientific World Journal
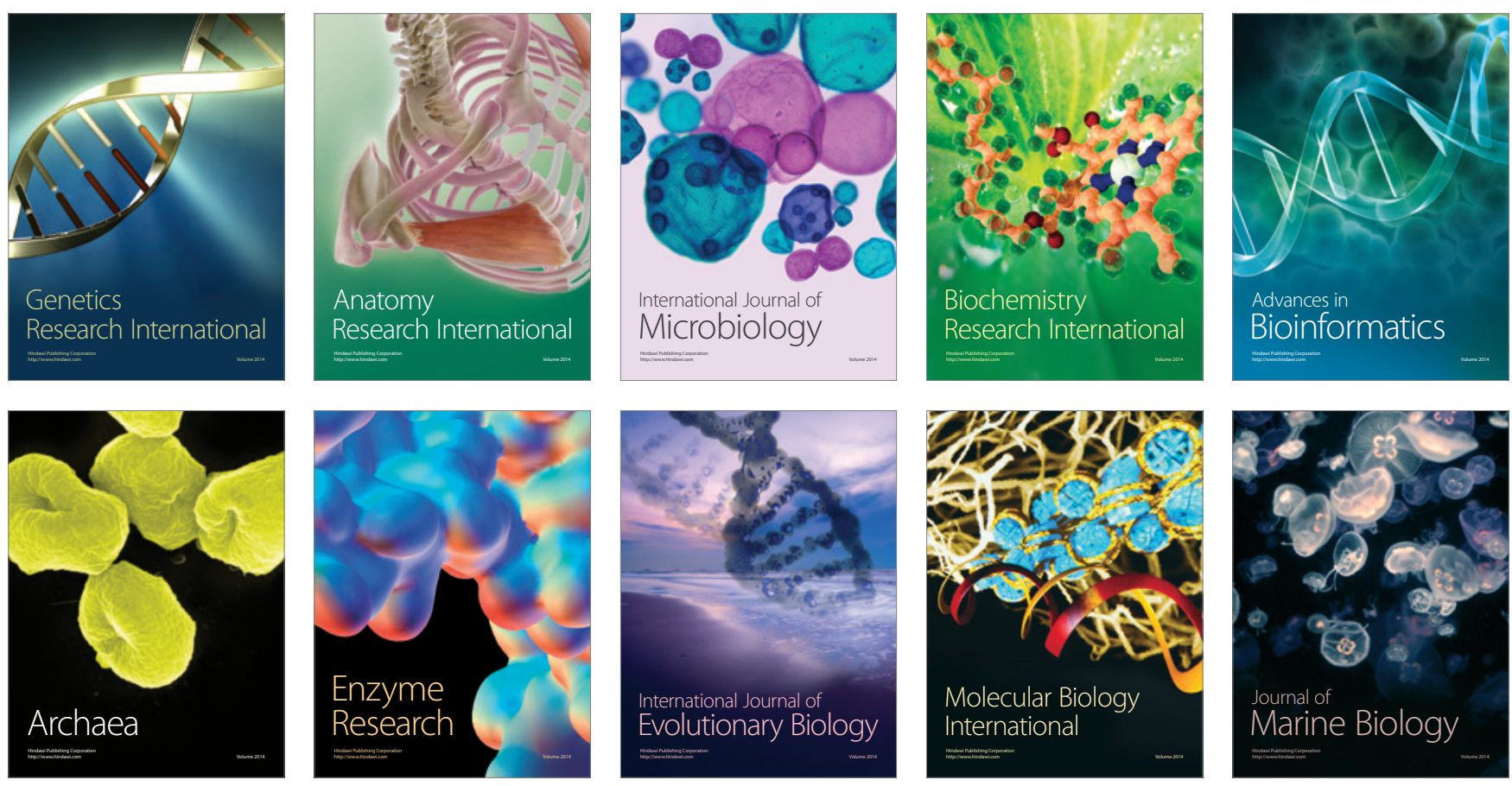